DOI: $10.14451 / 2.125 .7$

\title{
К ВОПРОСУ О ВЗАИМОДЕЙСТВИИ СПЕЦИАЛЬНОГО ДОКЛАДЧИКА ПО ВОПРОСУ О НЕЗАВИСИМОСТИ СУДЕЙ И АДВОКАТОВ С РОССИЙСКОЙ ФЕДЕРАЦИЕЙ
}

\author{
(c) 2018 Ширёва Ирина Викторовна \\ кандидат юридических наук, доцент \\ Департамент правового регулирования экономической деятельности \\ Финансовый университета при Правительстве Российской Федерации \\ 125993, г. Москва, Ленинградский пр-т, д. 49 \\ E-mail: IVShiryova@fa.ru \\ (c) 2018 Ширёв Денис Андреевич \\ адвокат Московской областной коллегии адвокатов (МОКА) \\ доцент кандидат юридических наук, доцент \\ кафедра Судебной власти, правоохранительной и правозащитной деятельности \\ Юридический Институт \\ Российский университет дружбы народов \\ 117198 , г. Москва, ул. Миклухо-Маклая, д. 6 \\ E-mail:ne205@yandex.ru
}

В статье рассматриваются вопросы, связанные с деятельностью одной из специальных тематических процедур Совета по правам человека $\mathrm{OOH}$ - Специального докладчика по вопросу о независимости судей и адвокатов; а также вопросы, связанные с посещением Специальным докладчиком Российской Федерации в 2008 г. и 2013 г.

Ключевые слова: Совет по правам человека ООН, специальные процедуры, права человека, правозащитные механизмы $\mathrm{OOH}$.

Специальный докладчик по вопросу о независимости судей и адвокатов является одним из особых правозащитных механизмов системы Организации Объединенных Наций, специальной тематической процедурой Совета ООН по правам человека [1], мандат которой был установлен изначально на три года в 1994 г. в процессе работы действовавшей с 1946 г. и прекратившей свою деятельность в 2006 г. Комиссией по правам человека." Впоследствии, в связи с необходимостью мандат Специального докладчика неоднократно продлевался [2].

Следует отметить что, в настоящее время полномочия докладчика в соответствии с имеющимся мандатом предусматривают:

- деятельность по расследованию соответствующих тревожащих утверждений или сообщений адресованных Специальному докладчику;

- выявление и фиксация случаев как посягательств на независимость судебных органов, адвокатов и должностных лиц судов, так и до- стигнутого прогресса в деле защиты и укрепления их независимости;

- предложение конкретных рекомендаций, включая предоставление, при необходимости, консультативных услуг или технической помощи;

- определение путей и средств совершенствования судебной системы и подготовка конкретных рекомендаций по этому вопросу;

- изучение с целью внесения предложений важных и актуальных принципиальных вопросов в целях защиты и укрепления независимости судебных органов, адвокатов и должностных лиц судов; продолжение сотрудничества, избегая при этом дублирования, с соответствующими органами, мандатами и механизмами Организации Объединенных Наций и с региональными организациями;

- представление на регулярной основе отчетов в виде докладов Совету по правам человека ООН в соответствии с его программой работы, а также Генеральной Ассамблее ООН [2].

\footnotetext{
* Напомним, Комиссия по правам человека была упразднена в 2006 г. взамен которой был создан Совет по правам человека, действующий в настоящее время.
} 
Специальный докладчик уполномочен принимать необходимые меры на основании представленной информации о предполагаемых нарушениях, связанных с независимостью и беспристрастностью судебных органов и независимостью юристов, направляя соответствующим правительствам письма с утверждениями и призывы к незамедлительным действиям с целью выяснения и/или доведения до их сведения этих случаев. Он может по приглашению соответствующего Правительства посещать интересующие страны, представляя после поездки доклад с отчетом в Совет по правам человека, содержащим выводы, рекомендации и заключения."

Так, сотрудничая с Российской Федерацией, по приглашению Правительства РФ Специальный докладчик по вопросу о независимости судей и адвокатов посещал дважды нашу страну, соответственно с 19 по 29 мая 2008 г." и с 15 по 25 апреля 2013 г."

В докладе по результатам первого визита в Россию в 2008 г. (а именно было посещение Москвы, Санкт-Петербурга, Екатеринбурга и Верхней Пышмы) Специальный докладчик по вопросу о независимости судей и адвокатов Леандро Деспуи [3] привел общую политическую, правовую и социально-экономическую информацию, подробно изложил структуру существующей общей судебной системы РФ, военной юрисдикции, экономических судов; были указаны основные недавние реформы и изменения, касающиеся судебной системы; приведены соответствующие данные о деятельности адвокатуры, прокуратуры; уделено внимание условиям труда в судебной системе; доле женщин в юридической профессии; были сделаны соответствующие выводы и даны краткие рекомендации в отношении институциональной и правовой основы, для укрепления процессуального законодательства и практики, для усиления независимой роли судей, в отношении Прокуратуры, в отношении сохранения и укрепления роли Адвокатуры.

Следующая миссия Специального докладчика по вопросу о независимости судей и адвокатов Габриэлы Кнауль в Российскую Федерацию состоялась через пять лет, соответственно, с 15 по 25 апреля 2013 года. Специальный докладчик посетила Москву, Санкт-Петербург, Ростов-на-Дону, Азов и Нижний Новгород. В докладе по результатам посещения Российской Федерации были отмечены вопросы, связанные с системой отправления правосудия в стране; указаны вызовы в вопросах независимости и беспристрастности судебной власти и надлежащего отправления правосудия; даны выводы и рекомендации. Среди выводов Специальный докладчик обозначила проблемные моменты:

- программы реформирования, включая новое законодательство, все еще не полностью реализованы;

- нельзя допускать, чтобы на судей и адвокатов оказывалось давление, им угрожали, их убивали в обстановке полной безнаказанности, любые случаи прямых или косвенных угроз в адрес судей, прокуроров или адвокатов, оказывания на них неправомерного воздействия или давления, или вмешательства в их работу должны незамедлительно пресекаться во избежание серьезных последствий для независимости системы отправления правосудия и обеспечения верховенства закона в Российской Федерации.

Ниже следует привести сформулированные Специальным докладчиком рекомендации и некоторые прокомментировать:

- Федеральная целевая программа «Развитие судебной системы России на 2013-2020 гг.» должна выполняться при полном и осознанном участии работников судебных органов, в том числе Верховного Суда, а также других заинтересованных сторон, адвокатов и членов коллегий адвокатов;

- всем государственным учреждениям Российской Федерации следует уважать и поддерживать независимость судебной власти;

- следует пересмотреть состав квалификационных коллегий и процедуры назначения их членов, принять меры для обеспечения их полной независимости и недопущения оказания на них политического влияния; назначения судей не должны производиться исполнительными органами;

- процедуры отбора и назначения должны быть транспарентными ${ }^{\text {*⿻*⿲二丨土口𧘇 }}$; необходимо обеспе-

\footnotetext{
* С отчетами можно ознакомиться на официальном сайте ООН в Информационно-телекоммуникационной сети Интернет

** Визит специального докладчика Леандро Деспуи.

*** Визит специального докладчика Габриэлы Кнауль.

**** Прозрачными. прим. автора.
} 
чить доступ общественности к соответствующим протоколам;

- при любом дисциплинарном производстве следует соблюдать право судей на справедливое разбирательство и пересмотр решения независимым органом;

- за наложение дисциплинарных взысканий на судей должен отвечать независимый орган;

- следует активизировать усилия по модернизации судов; оптимизировать использование технических средств, включая Интернет, базы данных, и видеоконференции на федеральном и региональном уровнях;

- информация и критерии, касающиеся распределения дел, должны быть известны общественности в порядке устранения подозрений в неправомерной практике и коррупции;

- необходимо вести надлежащие протоколы судебных заседаний;

- заключение под стражу до суда должно применяться не и систематически, а в исключительных случаях и должно быть основано на принимаемом в каждом конкретном случае решения о том, что оно обоснованно и необходимо;

- адвокатам необходимо предоставлять доступ к следственным материалам и ко всем доказательствам, собранным в ходе расследования, а также разрешать снимать копии с этих материалов; (Действительно после окончания расследования на этапе ознакомления в порядке ст. 217 УПК РФ нередко возникают ситуации когда следователи выдают адвокатам не прошитые тома уголовного дела, с непоследовательно проставленной нумерацией листов, незаполненными бланками описи листов тома(ов) уголовного дела. В этом проявляется, на наш взгляд, неуважение к стороне защиты. Однако, кому как не адвокатам добиваться от следователей уважения, законно требуя предоставлять для ознакомления оформленные надлежащим образом материалы уголовного дела).

- необходимо незамедлительно, беспристрастно и эффективно проводить расследования в связи с утверждениями о применении пыток, в том числе пыток с целью получения признательных показаний;

- не следует ограничивать юрисдикцию судов присяжных;

- следует активизировать усилия по обеспечению более эффективного исполнения национальных и международных судебных решений;
(В настоящее время в целях активизации исполнения судебных актов законодателем были криминализированы действия/бездействие за их не исполнение. Так ст. 315 УК РФ дополнена частью первой: «Злостное неисполнение вступивших в законную силу приговора суда, решения суда или иного судебного акта, а равно воспрепятствование их исполнению лицом, подвергнутым административному наказанию за деяние, предусмотренное частью 4 статьи 17.15 Кодекса Российской Федерации об административных правонарушениях, совершенное в отношении того же судебного акта». Данная норма предусматривает в качестве наказания до одного года лишения свободы [4]);

- решения Европейского суда по правам человека в отношении Российской Федерации следует должным образом исполнять, официально переводить на русский язык и размещать в общедоступных базах данных для беспрепятственного ознакомления с ними;

- адвокаты, назначенные для предоставления правовой помощи по уголовным делам, должны получать надлежащее вознаграждение за все свои услуги; (2 октября 2018 г. Правительство РФ приняло постановление № 1169 [5], предусматривающее поэтапное повышение размера вознаграждения адвокатов, участвующих в уголовном судопроизводстве по назначению органов дознания, предварительного следствия или суда. С 2019 г. минимальное вознаграждение за один рабочий день в дневное время будет составлять 900 руб., с 2020 г. - 1250 руб., с 2021 г. - 1500 руб. Увеличиваются также ставки оплаты участия адвоката в уголовном деле в ночное время, нерабочие праздничные или выходные дни.);

- следует принять всеобъемлющий административно-процессуальный кодекс; (Соглашаясь с мнением докладчика, отметим, что КоАП (КРФобАП) - единственный кодифицированный закон, содержащий нормы как материального, так и процессуального права, причём с очевидным преобладанием первых. Данное положение недопустимо поскольку, порождает в сознании правоприменителей ложное чувство неважности соблюдения процедуры по делам об АП и как следствие «незначительности» нарушений допускаемых при её производстве.).

- следует принять конкретные меры для создания системы административных судов в качестве средства, способствующего борьбе с 
безнаказанностью в случае совершения нарушений государственными служащими или их бездействия;

- необходимо организовывать специальную подготовку для судей административных судов;"

- на федеральном уровне необходимо рассмотреть возможность разработки и внедрения комплексной и инклюзивной системы ювенальной юстиции;

- следует сузить круг оснований для применения надзорных полномочий органов прокуратуры, а также четко прописать соответствующую процедуру в законодательстве;

- обязанность по регистрации адвокатов следует передать от министерства Юстиции са- мой адвокатуре;

- в тех случаях, когда возникает угроза безопасности адвокатов вследствие исполнения ими своих обязанностей, власти должны принимать эффективные меры для обеспечения их собственной безопасности и безопасности их семей.

В процессе анализа сформулированных рекомендаций и мониторинга последующих изменений национального законодательства авторы пришли к выводу о способности Российской Федерации конструктивно реагировать на критические замечания Специального докладчика по вопросу о независимости судей и адвокатов Совета по правам человека Организации Объединённых Наций.

\section{Библиографический список}

1. Ширёва И.В. Защита прав человека в рамках $\mathrm{OOH}$ и в ее специализированных учреждениях. Монография. Воронеж. 2012; Ширёва И.В. Механизмы защиты прав человека в рамках Организации Объединенных Наций и в ее специализированных учреждениях: дис. ... канд. юрид. наук. Москва, 2013; Ширёва И.В., Ширёв Д. А. Взаимодействие России и правозащитных механизмов системы ООН// Вопросы экономики и права. 2017. № 114. С.11-14.

2. URL: https://www.ohchr.org/RU/Issues/Judiciary/Pages/IDPIndex.aspx

3. Спецдокладчик ООН о судебной системе России [Текст] / Леандро Деспуи // Российский бюллетень по правам человека.- М., 2009.- Вып. 27.- С. 23-25.- Выводы.

4. УК РФ в ред. Федерального закона от 02.10.2018 № 348-ФЗ.

5. Постановление Российской Федерации от 2 октября 2018 г. № 1169 «О внесении изменения в Положение о возмещении процессуальных издержек, связанных с производством по уголовному делу, издержек в связи с рассмотрением дела арбитражным судом, гражданского дела, административного дела, а также расходов в связи с выполнением требований Конституционного Суда Российской Федерации». [Электронный ресурс - Официальный сайт Правительства Российской Федерации] - Режим доступа: http://static. government.ru/media/files/b7NPOFTAmA0R36YrQT5dKUbosW2oKoeA.pdf (дата обращения: 03.10.2018 г.).

Поступила в редакцию 07.11.2018

\footnotetext{
* Данная рекомендация требует дополнительного разъяснения, поскольку Кодекс административного судопроизводства РФ (КАС) был принят в апреле 2014 года и в сентябре того же года вступил в силу.
} 